\title{
KEPUTUSAN PEMBELIAN KONSUMEN PADA SITUS ONLINE TRAVELOKA DITINJAU DARI PERSEPSI HARGA DAN KUALITAS PELAYANAN
}

\author{
Oleh: \\ Yuli Triastuti'1), Jayadi'2), Widya Zura ${ }^{3)}$ \\ yulitrias@gmail.com ${ }^{11}$, djayadi.ipwija@gmail.com ${ }^{2}$, widyazuraa26@gmail.com ${ }^{3)}$ \\ Sekolah Tinggi Ilmu Ekonomi IPWI Jakarta1,2,3)
}

\begin{abstract}
ABSTRAK
Keputusan pembelian konsumen pada situs online Traveloka dipengaruhi oleh beberapa faktor antara lain persepsi harga dan kualitas pelayanan. Untuk membuktikan pengaruh keduanya maka dilakukan penelitian ini dengan tujuan untuk mengetahui bagaimana keputusan pembelian pada situs online Traveloka ditinjau dari persepsi harga dan kualitas pelayanan.

Penelitian dilakukan di Cibubur dengan mengambil 100 konsumen sebagai sampel penelitian dan dihitung menggunakan metode accidental sampling. Pengambilan data dilakukan dengan instrumen kuesioner tertutup lima skala penilaian. Penelitian dilakukan secara kuantitatif yaitu dengan mendeskripsikan data penelitian dan melakukan analisis inferensi. Analisis regresi linier ganda dan koefisien determinasi ganda digunakan sebagai alat analisis sedangkan pengujian hipotesis dilakukan dengan uji-t dan uji-F dengan bantuan program SPSS v.24.

Hasil penelitian ini menunjukan bahwa: 1) Keputusan pembelian konsumen pada situs online Traveloka mempunyai pengaruh yang positif ditinjau dari persepsi harga. 2) Keputusan pembelian konsumen pada situs online Traveloka mempunyai arah yang positif ditinjau dari kualitas pelayanan.

Berdasarkan hasil temuan tersebut maka untuk meningkatkan keputusan pembelian disarankan agar dilakukan upaya terus menerus selalu memperbaiki tentang persepsi harga dan kualitas pelayanan.
\end{abstract}

Kata Kunci: Persepsi Harga, Kualitas Pelayanan, Keputusan Pembelian

\section{PENDAHULUAN}

Teknologi memegang peranan penting dalam proses dan praktik komunikasi di tengah masyarakat industri yang bertransformasi menjadi masyarakat informasi. Teknologi informasi dari waktu ke waktu semakin maju dan pesat, dampaknya sudah terasa oleh sebagian besar masyarakat dari yang sederhana menjadi modern dan serba cepat. Teknologi mempunyai peranan penting bagi kehidupan masyarakat sehari-hari, dilihat dari banyaknya pengguna internet. Yang awalnya masyarakat Indonesia hanya menggunakan media massa dan cetak (seperti koran, majalah, televisi, radio) saja untuk mendapatkan informasi, namun saat ini masyarakat mulai beralih menggunakan internet, karena internet bersifat luas dan tidak terbatas, yang dapat digunakan oleh manusia kapanpun dan dimanapun mereka berada. Dapat dilihat dari peningkatan pengguna internet yang setiap tahunnya terus meningkat.

Perkembangan teknologi yang semakin canggih membawa sistem pemasaran juga berkembang. Dengan adanya kemajuan teknologi, sistem jual beli tidak hanya dilakukan dengan cara langsung, melainkan dengan memanfaatkan kekuatan media internet, para pemilik bisnis berlomba-lomba untuk membuka usahanya melalui 
media internet atau yang biasa disebut e-commerce.

Gambar 1

Pengguna Internet di Indonesia

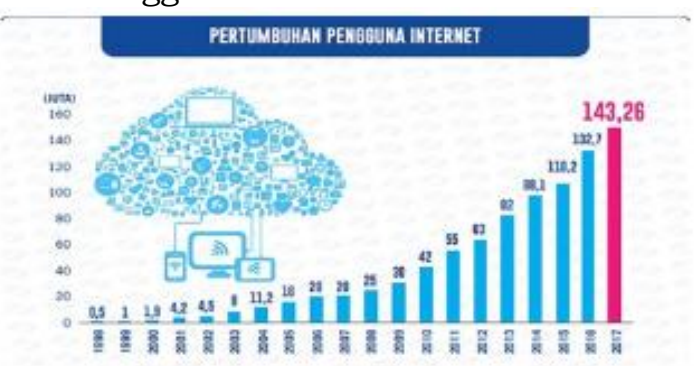

Sumber : APJII (Asosisasi Penyelenggara Jasa Internet Indonesia)

Jika dulu masyarakat membeli tiket pesawat di bandara dan agen, sekarang dengan berkembangnya teknologi masyarakat bisa dengan mudahnya memesan tiket pesawat tanpa membutuhkan waktu yang lama dan harga tiket pesawat yang mahal karena terdesak. Dengan semakin bertambahnya mobilitas penduduk menggunakan pesawat terbang, Saat ini bisnis jasa tiket pesawat telah menggunakan sistem online. Masyarakat bisa memesan tiket pesawat melalui aplikasi mobile online booking yang dinilai sangat mudah, cepat, dan praktis. Saat ini terdapat banyak perusahaan-perusahaan yang menyediakan pembelian tiket pesawat secara online dengan cepat dan praktis, di antaranya traveloka.com, tiket.com, trivago.co.id, utiket.com, nusatrip.com.

Konsumen sangat dimudahkan dengan adanya situs penjualan tiket pesawat secara online karena sangat efektif. Biasanya, konsumen melakukan pencarian informasi terlebih dahulu sebelum memesan tiket pesawat pada sebuah situs online dan bisa membandingkan harga sesuai budget yang dimiliki.

Traveloka merupakan perusahaan yang bergerak dalam bidang pelayanan pemesanan tiket pesawat dan reservasi hotel secara online. Traveloka pertama kali didirikan oleh Ferry Unardi, Derianto Kusuma, dan Albert yang pada awalnya hanya sebuah konsep untuk melihat dan membandingkan harga (Majalah SWA, 2014). Pembayaran tiket dan reservasi hotel Traveloka dapat dilakukan dengan mudah, nyaman, dan aman. Traveloka telah menjalin support dan kerjasama dengan bank-bank ternama di Indonesia melalui ATM bersama, Prima, dan ALTO. Sehingga keamanan konsumen dalam bertransaksi dapat terjaga (traveloka.com).

Strategi manajemen Traveloka ialah mengembangkan produk dan layanan yang memikat. Pengembangan aplikasi dengan menggarap kue bisnis tiket online melalui berbagai produk. Pada Juli 2014, Traveloka merilis layanan pemesanan kamar hotel. Mei 2016, manajemen meluncurkan fitur Easy Reschedule yang menyediakan kemudahan mengubah jadwal penerbangan. Tak berhenti di situ, Traveloka melansir price alert di Agustus 2016 untuk mempermudah pelanggan dalam menemukan tiket pesawat yang terjangkau. Selanjutnya, Januari 2017 memberikan layanan untuk pemesanan atraksi \& rekreasi dan pemesanan tiket kereta pada Maret 2017 (Majalah SWA, 2018). Dalam penelitian ini yaitu bagaimana keputusan pembelian konsumen pada situs online Traveloka ditinjau dari persepsi harga dan kualitas pelayanan.

\section{TUJUAN PENELITIAN}

Tujuan penelitian ini adalah untuk mengetahui bagaimana keputusan pembelian pada situs online Traveloka ditinjau dari persepsi harga dan kualitas pelayanan.

\section{TELAAH LITERATUR DAN PENGEMBANGAN PROPOSISI/HIPOTESIS Keputusan Pembelian}

Di dalam teknik pengambilan keputusan tentu saja ada yang mempengaruhi. Adapun faktor-faktor yang mempengaruhi pengambilan keputusan adalah pertama nilai individu, dimana nilai individu ini akan sangat berpengaruh terhadap diri sesorang dalam mengambil keputusan. Kedua kepribadian, jelaslah bahwa 
kepribadian seseorang akan sangat berpengaruh terhadap pengambilan keputusan. Ketiga kecenderungan dalam mengambil resiko.

Keputusan pembelian akan dipengaruhi juga oleh kualitas produk, hal ini sesuai dengan hasil penelitian yang dilakukan oleh Fatmawati dan Soliha pada tahun 2017 dengan judul Kualitas Produk, Citra Merek, dan Persepsi Harga terhadap Proses Keputusan Pembelian Konsumen Sepeda Motor Merek Honda. Hasil penelitian ini menjelaskan bahwa kualitas produk, citra merek, dan persepsi harga berpengaruh positif dan signifikan terhadap keputusan pembelian.

Keputusan pembelian merupakan suatu proses pengambilan keputusan akan pembelian yang mencakup penentuan apa yang akan dibeli atau tidak melakukan pembelian dan keputusan itu diperoleh oleh kegiatankegiatan sebelumnya (Assauri, 2004:141 dalam Romdonah, 2015:2).

Seperti halnya penelitian Sari pada tahun 2016 di Daerah Istimewa Yogyakarta dengan tujuan menganalisis pengaruh citra merek fitur dan persepsi harga mempengaruhi keputusan pembelian, hasil penelitian ini menunjukan arah positif dan signifikan tentang bagaimana persepsi harga yang berpengaruh terhadap keputusan pembelian konsumen.

\section{Persepsi Harga}

Harga merupakan salah satu atribut paling penting yang dievaluasi oleh konsumen, dan manajer harus benarbenar menyadari peran tersebut dalam pembentukan sikap konsumen. Pada kondisi tertentu konsumen sangat sensitif terhadap harga suatu produk yang relatif lebih tinggi dibandingkan para persaingnya dapat mengeliminasi produk dari perimbangan konsumen (Sangadji dan Sopiah, 2013:206).

Penetapan harga merupakan tugas kritis yang menunjang keberhasilan operasi organisasi profit maupun nonprofit. Harga merupakan satu-satunya unsur bauran pemasaran yang mendatangkan pendapatan bagi organisasi. Keputusan harga tidak mudah dilakukan. Di satu sisi, harga mahal dapat meningkatkan laba jangka pendek, tetapi di sisi lain akan sulit dijangkau oleh konsumen. Sedangkan bila harga terlalu murah, pangsa pasar bisa bergejolak, akan tetapi marjin kontribusi dan laba bersih yang diperoleh bisa jadi amat kecil, bahkan tidak cukup untuk mendukung pertumbuhan atau ekspansi organisasi (Tjiptono dan Chandra, 2012:315).

Seperti halnya penelitian yang dilakukan oleh Norcahyo pada tahun 2016 dengan judul Analisis Pengaruh Persepsi Harga, Kualitas Pelayanan, World Of Mouth terhadap Keputusan Pembelian Pengunjung Taman Joglo Cafe dimana tujuannya adalah untuk mengetahui persepsi harga dan kualitas pelayanan lokasi World Of Mouth terhadap keputusan pembelian. Hasilnya mempunyai pengaruh yang positif dan signifikan.

\section{Kualitas Pelayanan}

Kualitas pelayanan menjadi suatu keharusan yang harus dilakukan perusahaan supaya mampu bertahan dan tetap mendapat kepercayaan pelanggan. Keberhasilan perusahaan dalam memberikan pelayanan yang berkualitas dapat ditentukan dengan pendekatan service quality yang dikembangkan oleh Parasuraman, Berry dan Zenthaml (dalam Ika, 2010).

Kualitas merupakan suatu kondisi dinamis yang berpengaruh dengan produk, jasa, manusia, proses, dan lingkungan yang memenuhi atau melebihi harapan (Tjiptono, 2012). Kualitas pelayanan dapat diartikan sebagai upaya pemenuhan kebutuhan dan keinginan konsumen. Kualitas pelayanan (service quality) dapat diketahui dengan cara atau perolehan dengan pelayanan yang sesungguhnya mereka harapkan. Jika jasa yang diterima atau dirasakan sesuai dengan yang diharapkan, maka kualitas pelayanan dipersepsikan baik dan memuaskan. Sebaliknya jika jasa yang diterima lebih rendah daripada yang diharapkan, maka kualitas pelayanan dipersepsikan buruk/tidak sesuai dengan harapan konsumen. 
Kualitas pelayanan merupakan hal utama yang dapat mempengaruhi keputusan pembelian. Menurut Tjiptono dan Candra (2012:77) menyatakan bahwa kualitas pelayanan mencerminkan perbandingan antara tingkat pelayanan yang disampaikan perusahaan dibandingkan ekspetasi konsumen. Pelayanan dapat dikatakan baik atau berkualitas apabila pelayanan yang diberikan oleh suatu perusahaan dapat memuaskan para konsumen. Jika konsumen merasa puas dengan pelayanan yang diberikan maka tidak menutup kemungkinan bahwa konsumen akan loyal terhadap perusahaan.

\section{Pengaruh Persepsi Harga dan Kualitas Pelayanan terhadap Keputusan Pembelian Konsumen}

Persepsi terhadap harga suatu produk/jasa oleh konsumen selalu berbeda-beda. Konsumen memiliki pertimbangan terhadap harga yang mahal atau murah tergantung kebutuhan. Jika harga sesuai dengan kebutuhan, maka konsumen tidak akan ragu dalam memutuskan untuk membeli produk/jasa tersebut.

Pelayanan yang baik selalu mendahulukan kepuasan konsumen. Jika pelayanan yang ada seseuai dengan ekspetasi konsumen, maka konsumen akan mempertimbangkan untuk pembelian produk/jasa di perusahaan tersebut.

Oleh karena itu, dapat diduga bahwa persepsi harga dan kualitas pelayanan berpengaruh terhadap keputusan pembelian konsumen.

Berdasar uraian di atas, maka kerangka pengaruh antar variabel dalam penelitian ini dapat digambarkan sebagai berikut:

Gambar 2

Kerangka/Konstelasi

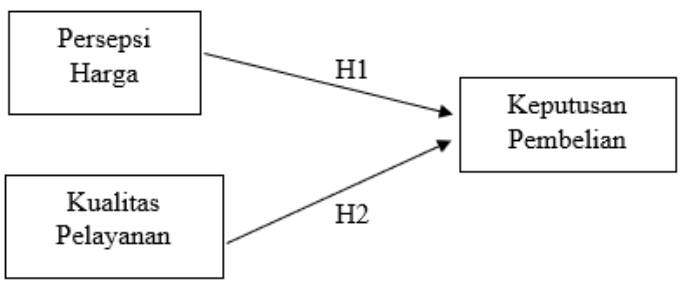

H1: Keputusan pembelian konsumen pada situs online Traveloka mempunyai pengaruh yang positif dan signifikan ditinjau dari persepsi harga.

H2: Keputusan pembelian konsumen pada situs online Traveloka mempunyai arah yang positif dan signifikan ditinjau dari kualitas pelayanan.

\section{METODE PENELITIAN}

Penelitian ini diadakan pada situs online Traveloka. Penelitian dilaksanakan selama 4 bulan.

\section{Sampel Penelitian}

Sampel pada penelitian ini adalah konsumen Traveloka. Penentuan jumlah sampe penelitian dilakukan dengan perhitungan sampel untuk populasi tak terhingga (Mulyanto dan Wulandari, 2010:103) dengan margin error 1\% yaitu sebagai berikut:

$n=\frac{Z_{a}^{2}(\mathrm{p} \cdot \mathrm{q})}{e^{2}}$

$n=\frac{1.96^{2} \times 0.5 \times 0.5}{0.01}$

$n=96,04$ dibulatkan menjadi 100 sampel

Ket:

$\mathrm{n}=$ jumlah sampel

$\mathrm{N}=$ jumlah populasi

$Z a=$ level of confidence atau nilai $Z(Z$ score)

$\mathrm{P}=$ variabilitas populasi (persentase)

$\mathrm{q}=100 \%-\mathrm{p}$

$\mathrm{e}=$ margin $/$ sampling error

Metode yang digunakan dalam pengambilan sample adalah accidental sampling. Dimana yang dimaksud accidental sampling yaitu metode pengambilan sampel dengan memilih siapa yang kebetulan ditemui atau dijumpai.

\section{Desain Penelitian}

Jenis penelitian yang digunakan dalam penelitian ini adalah explanatory research tipe kausal menguji pengaruh variabel independen terhadap variabel dependen. Lingkup penelitian ini adalah menguji pengaruh persepsi harga dan kualitas pelayanan terhadap keputusan pembelian konsumen pada situs online Traveloka. 
Dalam penelitian ini terdapat tiga variabel, Yaitu variabel bebas ada dua dan satu variabel terikat. Variabel bebas yang pertama yaitu persepsi harga dengan simbol X1 dan variabel bebas yang kedua yaitu kualitas pelayanan dengan simbol X2. Satu variabel terikat yaitu keputusan pembelian konsumen dengan simbol Y.

Pengukuran variabel penelitian dilakukan dengan menggunakan kuesioner yang dikembangkan dari indikator pada masing-masing variabel penelitian.

\section{Operasionalisasi Variabel}

Operasionalisasi variabel berupa definisi dan indikator masing-masing variable sebagai berikut:

Tabel 1

Operasionalisasi Variabel

\begin{tabular}{|c|c|c|}
\hline Variabel & Dimensi & Indikator \\
\hline $\begin{array}{l}\text { Persepsi Harga (X1) adalah biaya } \\
\text { relative yang hanus konsumen } \\
\text { keluarkan untuk memperoleh } \\
\text { produk atau jasa yang ia inginkan. } \\
\text { Rangkuti (2008:103) }\end{array}$ & $\begin{array}{l}\text { - Harga } \\
\text { - Layanan } \\
\text { - Fasilitas }\end{array}$ & $\begin{array}{l}\text { 1. Harga terjangkau } \\
\text { 2. Sesuai layanan } \\
\text { yang akan } \\
\text { diterima } \\
\text { 3. Sesuai fasilitas } \\
\text { yang akan } \\
\text { diterima } \\
\text { 4. Lebih murah dari } \\
\text { pesaing }\end{array}$ \\
\hline $\begin{array}{l}\text { Kualitas Pelayanan (X2) adalah } \\
\text { totalitas fitur dan karakteristik } \\
\text { dari suatu produk atau jasa yang } \\
\text { menanggung pada kemampuannya } \\
\text { untuk memuaskan kebutuhan } \\
\text { yang dinyatakan atau tersirat. } \\
\text { Kotler \& Keller (2012:153) }\end{array}$ & $\begin{array}{l}\text { - Kesesuaian, } \\
\text { - kemudahan, } \\
\text { - kehandalan, } \\
\text { - ketepatan }\end{array}$ & $\begin{array}{l}\text { 1. Keandalan / } \\
\text { Kemampuan } \\
\text { mewujudkan janji } \\
\text { 2. Ketanggapan } \\
\text { dalam } \\
\text { memberikan } \\
\text { layanan } \\
\text { 3. Keyakinan atau } \\
\text { kemampuan } \\
\text { memberikan } \\
\text { jaminan } \\
\text { pelayanan } \\
\text { 4. Memahami } \\
\text { keinginan } \\
\text { konsumen } \\
\text { 5. Tampilan fisik } \\
\text { pelayanan }\end{array}$ \\
\hline $\begin{array}{l}\text { Keputusan Pembelian (Y) adalah } \\
\text { sebuah proses dimana konsumen } \\
\text { mengenal masalahnya, mencari } \\
\text { informasi mengenai produk atau } \\
\text { merek tertentu dan mengevaluasi } \\
\text { seberapa baik masing-masing } \\
\text { alternatif tersebut dapat } \\
\text { memecahkan masalahnya, yang } \\
\text { kemudian mengarah kepada } \\
\text { keputusan pembelian. } \\
\text { Fandy Tjiptono (2014:21) }\end{array}$ & $\begin{array}{l}\text { - Pembelian } \\
\text { ulang } \\
\text { - Merekomendas } \\
\text { ikan } \\
\text { - Tidak mudah } \\
\text { pindah }\end{array}$ & $\begin{array}{l}\text { 1. Sesuai atribut } \\
\text { dengan keinginan } \\
\text { dan kebutuhan } \\
\text { 2. Pertimbangan } \\
\text { dalam membeli } \\
\text { 3. Kemantapan } \\
\text { membeli }\end{array}$ \\
\hline
\end{tabular}

\section{Metode Analisis}

Untuk menyelesaikan hubungan tersebut digunakan rumus persamaan linier sebagai berikut:

$$
\mathrm{Y}=\mathrm{a}+\mathrm{bX} 1+\mathrm{bX} 2
$$

Dimana :

$\mathrm{Y}=$ subjek variabel terikat yang diproyeksikan

$\mathrm{a}=$ nilai konstanta $\mathrm{Y}$ jika nilai $\mathrm{X}=0$

$\mathrm{b}=$ nilai arah sebagai penentu ramalan variabel Y

$\mathrm{x}=$ variabel bebas yang mempunyai nilai tertentu untuk diprediksikan

(Riduwan, 2007:96).

\section{HASIL DAN PEMBAHASAN \\ Hasil Penelitian}

Dari uji validitas terhadap masingmasing variabel penelitian ditemukan bahwa semua item pertanyaan dalam kuesioner penelitian mempunyai koefisien korelasi $r$ hitung yang lebih besar dari $r$ tabel $=0,1966$ sehingga item pertanyaan tersebut valid. Melalui uji reliabilitas ditemukan bahwa keseluruhan variabel memiliki Cronbach Alpha yang lebih besar dari 0,60, sehingga variabel penelitian ini dapat dibuktikan reliabilitasnya. Karena kuesioner telah valid dan reliabel maka kuesioner penelitian merupakan alat yang handal untuk mengukur masingmasing variabel penelitian.

Analisis deskriptif terhadap variabel penelitian menghasilkan temuan yang relatif sama untuk semua variabel penelitian dimana persepsi responden terhadap persespsi harga, kualitas pelayanan, dan keputusan pembelian cenderung baik.

\section{Pengujian Hipotesis}

\section{Hipotesis 1 (H1) Pengaruh Persepsi Harga terhadap Keputusan Pembelian}

Keputusan pembelian konsumen pada situs online Traveloka mempunyai pengaruh yang positif dan signifikan ditinjau dari persepsi harga. Hipotesis pertama yang diajukan dalam penelitian ini adalah terdapat pengaruh persepsi harga terhadap keputusan pembelian pada situs online Traveloka. Pengaruhnya ditunjukkan oleh nilai koefisien regresi persepsi harga (X1) sebesar $b 1=0,506$ pada model persamaan regresi linier ganda $\mathrm{Y}=$ $0,429+0,506 \mathrm{X} 1+0,527 \mathrm{X} 2$. Hipotesis statistik yang diajukan sebagai berikut: 
H1o $: \mathrm{b} 1=0:$ tidak ada pengaruh

$\mathrm{H} 1 \mathrm{a}: \mathrm{b} 1 \neq 0$ : ada pengaruh

Koefisien regresi persepsi harga (X1) sebesar $\mathrm{b} 1=0,506$ memiliki nilai probabilitas $t$ hitung sebesar 0,000. Karena $\mathrm{b} 1 \neq 0$ dan probabilitas t hitung lebih kecil daripada taraf uji penelitian ( sig $\mathrm{t}<\mathrm{a}$ atau 0,000 $<0,05$ ), maka H1o ditolak dan $\mathrm{H} 1 \mathrm{a}$ diterima yang berarti pengaruh persepsi harga (X1) terhadap keputusan pembelian (Y) adalah signifikan. Signifikansi hasil pengujian menunjukkan bahwa hipotesis pertama penelitian ini diterima yang berarti keputusan pembelian konsumen pada situs online Traveloka mempunyai pengaruh yang positif dan signifikan ditinjau dari persepsi harga.

\section{Hipotesis 2 (H2) Pengaruh Kualitas Pelayanan terhadap Keputusan Pembelian}

Keputusan pembelian konsumen pada situs online Traveloka mempunyai arah yang positif dan signifikan ditinjau dari kualitas pelayanan. Hipotesis kedua yang diajukan dalam penelitian ini adalah terdapat pengaruh kualitas pelayanan terhadap keputusan pembelian pada situs online Traveloka. Pengaruhnya ditunjukkan oleh nilai koefisien regresi kualitas pelayanan (X2) sebesar b2 $=0,527$ pada model persamaan regresi linier ganda $\mathrm{Y}=$ $0,429+0,506 \mathrm{X} 1+0,527 \mathrm{X} 2$. Hipotesis statistik yang diajukan sebagai berikut:

H2o : b2 = 0 : tidak ada pengaruh

$\mathrm{H} 2 \mathrm{a}: \mathrm{b} 2 \neq 0$ : ada pengaruh

Koefisien regresi kualitas pelayanan (X2) sebesar b2 $=0,527$ memiliki nilai probabilitas $\mathrm{t}$ hitung sebesar 0,000. Karena $b 1 \neq 0$ dan probabilitas $t$ hitung lebih kecil daripada taraf uji penelitian ( sig $\mathrm{t}<\mathrm{a}$ atau 0,000 $<0,05$ ), maka H2o ditolak dan $\mathrm{H} 2 \mathrm{a}$ diterima yang berarti pengaruh kualitas pelayanan (X2) terhadap keputusan pembelian (Y) adalah signifikan. Signifikansi hasil pengujian menunjukkan bahwa hipotesis kedua penelitian ini diterima yang berarti keputusan pembelian konsumen pada situs online Traveloka mempunyai arah yang positif dan signifikan ditinjau dari kualitas pelayanan.

\section{Pembahasan}

Penelitian menghasilkan persamaan regresi linier ganda $\mathrm{Y}=-0,429+0,506$ $\mathrm{X} 1+0,527 \mathrm{X} 2$ yang layak untuk menjelaskan pengaruh persepsi harga dan kualitas pelayanan terhadap keputusan pembelian ( $\mathrm{R}$ Square $=0,684$ ) dimana persepsi harga dan kualitas pelayanan dalam model tersebut mampu menjelaskan $68,4 \%$ variasi keputusan pembelian.

\section{Pengaruh Persepsi Harga terhadap Keputusan Pembelian}

Persepsi harga memiliki pengaruh signifikan sebesar 50,6\% terhadap keputusan pembelian dengan arah positif, artinya makin tinggi persepsi harga maka makin tinggi pula keputusan pembelian. Pengaruh persepsi harga terhadap keputusan pembelian ditunjukkan oleh nilai koefisien regresi persepsi harga sebesar $\mathrm{b} 1=0,506$ pada model persamaan regresi linier ganda $\mathrm{Y}=-0,429+0,506$ $\mathrm{X} 1+0,527 \mathrm{X} 2$.

Faktor pertama yang mempengaruhi keputusan pembelian adalah persepsi harga. Persepsi harga adalah biaya relatif yang harus konsumen keluarkan untuk memperoleh produk atau jasa yang diinginkan. Dalam suatu kegiatan jual beli, diperlukan penetapan harga terhadap produk maupun jasa yang diperdagangkan, karena lewat harga kita pun dapat menilai gambaran kualitas dari produk/jasa tersebut (Priyanto, 2013).

Persepsi konsumen terhadap suatu harga dapat mempengaruhi keputusannya dalam membeli suatu produk. Oleh karena itu setiap produsen akan berusaha memberikan persepsi yang baik terhadap produk atau jasa yang mereka jual (Yosep, 2013). Hasil penelitian ini sesuai dengan penelitian yang dilakukan oleh Sari (2016).

\section{Pengaruh Kualitas Pelayanan terhadap Keputusan Pembelian}

Kualitas pelayanan memiliki pengaruh signifikan sebesar $52,7 \%$ terhadap keputusan pembelian dengan arah positif, artinya makin tinggi Kualitas pelayanan maka makin tinggi 
pula keputusan pembelian. Pengaruh kualitas pelayanan terhadap keputusan pembelian ditunjukkan oleh nilai koefisien regresi persepsi harga sebesar b2 $=0,527$ pada model persamaan regresi linier ganda $\mathrm{Y}=-0,429+0,506$ $\mathrm{X} 1+0,527 \mathrm{X} 2$.

Faktor kedua yang mempengaruhi keputusan pembelian adalah kualitas pelayanan. Menurut Kotler dan Keller (2012:153) menyatakan kualitas pelayanan adalah totalitas fitur dan karakteristik dari suatu produk atau jasa yang menanggung pada kemampuannya untuk memuaskan kebutuhan yang dinyatakan atau tersirat.

Hasil penelitian ini sesuai dengan penelitian yang dilakukan oleh Kodu (2013) dengan penelitiannya yang berjudul "Harga, Kualitas Produk dan Kualitas Pelayanan Pengaruhnya terhadap Keputusan Pembelian Mobil Toyota Avanza" yang menyatakan bahwa Kualitas Pelayanan secara simultan maupun parsial berpengaruh signifikan terhadap keputusan pembelian.

Penelitian yang dilakukan oleh Efendi (2017) dengan penelitiannya yang berjudul Pengaruh Harga, Lokasi, dan Kualitas Pelayanan terhadap Keputusan Pembelian di Warung Kopi D'Jaiz Kediri yang menyatakan bahwa ada pengaruh signifikan secara simultan antara kualitas pelayanan terhadap keputusan pembelian.

\section{KESIMPULAN}

\section{Simpulan}

- Persepsi harga memiliki pengaruh terhadap keputusan pembelian pada situs online Traveloka dengan arah positif sebesar $b 1=0,506$, artinya makin tinggi persepsi harga maka makin tinggi pula keputusan Pembelian di Traveloka.

- Kualitas pelayanan memiliki pengaruh terhadap keputusan pembelian pada situs online Traveloka dengan arah positif b2 = 0,527 , artinya makin tinggi kualitas pelayanan maka makin tinggi pula Saran
- Selalu melakukan analisa harga untuk mendapatkan harga yang sesuai dengan keinginan konsumen.

- Selalu memberikan pelatihan kepada seluruh tenaga kerja agar memberikan pelayanan yang semakin baik dan semakin baik untuk konsumennya.

\section{DAFTAR PUSTAKA}

Efendi, Dwi Andriya. 2017. Pengaruh Harga, Lokasi, dan Kualitas Pelayanan terhadap Keputusan Pembelian di Warung Kopi D'Jaiz Kediri. Simki-Economic. Vol. 01 No. 09.

Fatmawati, A. N dan Soliha. E. 2017. Kualitas Produk, Citra Merek, dan Persepsi Harga terhadap Keputusan Pembelian Konsumen Sepeda Motor Matic "Honda". Jurnal Manajemen Teori dan Terapan, Tahun 10, No. 1.

Hendra, D. 2018. Dari Jakarta Traveloka Menembus Pasar Regional. https://swa.co.id.

Ismayanti, Ika Putri. 2010. Analisis Pengaruh Kualitas Produk, Kualitas Pelayanan, Harga, dan Tempat terhadap Keputusan Pembelian (Studi Kasus pada Rumah Makan Soto Angkring Mas Boed di Semarang). Skripsi. Semarang: Fakultas Ekonomi Universitas Diponergoro.

Kodu, S. 2013. Harga, Kualitas Produk dan Kualitas Pelayanan Pengaruhnya terhadap Keputusan Pembelian Mobil Toyota Avanza. Jurnal EMBA. Vol. 1, No. 3:12511259.

Kotler, Philip dan K. L. Keller. 2012. Marketing Managemet. 14th Edition. London: Pearson Prentice Hall.

Mulyanto, Heru dan Wulandari, A. 2010. Penelitian: Metode dan Analisis, Semarang: CV. Agung.

Priyanto, David. 2013. Analisis Antecedents Keputusan Pembelian. http://repository.uksw .edu/bitstream/123456789/3655/ 2/T1_212007116_Full\%20text.pdf. 
Diakses pada 12 November 2016. Hal 7.

Romdonah, Rinda, dkk. 2015. Pengaruh Inovasi Produk, Harga, dan Brand Image terhadap Keputusan Pembelian Sepeda Motor Honda Beat (Studi Kasus pada Konsumen Dealer Honda Pratama Kurnia Kasih). Jurnal Universitas Pandanaran. Vol. 1 No. 1.

Sangaji, E. M dan Sopiah. 2013. Perilaku Konsumen. Yogyakarta: Andi Offset.
Sari, Hutami Permita. 2016. Pengaruh Citra Merek, Fitur, dan Persepsi Harga terhadap Keputusan Pembelian (Studi pada Konsumen Smartphone Xiaomi di DIY). Skripsi. Yogyakarta: Fakultas Ekonomi Universitas Negeri Yogyakarta.

Tjiptono, Fandi dan Chandra Gregorius. 2012. Pemasaran Strategik. Yogyakarta: Andi.

https://www.traveloka.com 